\title{
CONGRESS OF ARAB RED CRESCENT AND RED CROSS SOCIETIES
}

The Ninth Congress of Arab Red Crescent and Red Cross Societies, held at Algiers from 28 to 31 March 1977, was attended by representatives of fourteen National Societies of Arab countries, of twelve other Societies from Africa, Asia and Europe, and delegates of three Red Cross and Red Crescent societies in process of formation awaiting recognition. The ICRC, the League of Red Cross Societies, the Henry Dunant Institute and the League of Arab States also sent representatives.

This was the first time that the Congress had invited non-Arab Societies to send observers. They only took part in the discussion of matters of general interest, where their observations were received with interest. These meetings enabled the guests to get to know better the Arab Societies and their special problems, and there was no doubt that the exchange of ideas was productive.

The Executive Council of the Arab Red Crescent and Red Cross Societies Secretariat had devised an extensive agenda. The Congress examined at first those questions which were specifically of concern to the Arab Societies and their secretariat, and then dealt with relations between those Societies and the international bodies of the Red Cross: the work of the ICRC in Lebanon and the occupied territories; participation of Arab National Societies and co-operation between the ICRC and the Arab League in relief work in Lebanon; study of the new constitution of the League of Red Cross Societies and examination of some decisions taken by its latest Board of Governors; bye-laws of the League and the introduction of Arabic; exchanges of views on the report on the study of the re-appraisal of the role of the Red Cross.

The Congress decided to organize, next November in Alexandria, a seminar on the dissemination of knowledge of the Geneva Conventions and of Red Cross principles and it asked the ICRC to take part in its work. 
In one of its decisions, the Congress "stressed its deep appreciation of the importance of the humanitarian role which the International Committee of the Red Cross played in Lebanon and expressed the hope that the International Committee would pursue its activities, at the same time extending its thanks to the Committee for its action which it carried out from the beginning of the operations."

The participants all agreed that the Congress in Algiers was a success. The pleasant atmosphere, the delegates' constructive attitude and their wish to co-operate in harmony and to progress were all signs of the fruitful results that might be expected in the future.

\section{CENTENARY OF THE RED CROSS SOCIETY OF FINLAND ${ }^{1}$}

After the war of 1808-09 between Russia and Sweden, Finland, as an autonomous grand-duchy, whose sovereign was the Czar of Russia, became a part of the Russian Empire, but with its own Diet and its own administration. It remained so until 1917, when it became independent. The history of Finland during the 19th century is thus tied up with the history of Russia.

The Red Cross idea reached Finland through the Imperial Court of St. Petersburg. The initiative to found in Finland an independent Red Cross society was taken by Countess Aline Armfelt, wife of the Finnish Minister, State Secretary at the Imperial Court. In April 1877, when the Russo-Turkish war broke out, the project took form and the constitutive assembly of the Finnish Society for the Care of Sick and Wounded Soldiers was held at the Town Hall of Helsinki on 7 May 1877.

The statutes of the new society, confirmed by the Imperial Senate for Finland, stipulate that the society is an independent National Red Cross Society which, however, in case of war, would be allied with the Russian Red Cross, founded ten years earlier.

The first practical task of the society was to equip an ambulance-in fact a full surgical hospital with 50 beds-and to send it to the theatre of war. Under the leadership of Doctor Leopold Krohn, an experienced war surgeon, the ambulance was sent to the Caucasian front and it

\footnotetext{
1 Plates.
} 